\title{
The Sustainability of Dual Earner at the Workplace in Malaysia
}

\author{
Noor Rahamah Hj. Abu Bakar ${ }^{1} \&$ Mohd. Yusof Hj. Abdullah ${ }^{2}$ \\ ${ }^{1}$ School of Social, Development and Environmental Studies, Faculty of Social Science and Humanities, \\ Universiti Kebangsaan Malaysia, Bangi, Malaysia \\ ${ }^{2}$ School of Media and Communication, Faculty of Social Science and Humanities, Universiti Kebangsaan \\ Malaysia, Bangi, Malaysia \\ Correspondence: Noor Rahamah Hj. Abu Bakar, School of Social, Development and Environmental Studies, \\ Faculty of Social Science and Humanities, Universiti Kebangsaan Malaysia, 436000 UKM Bangi, Selangor \\ Darul Ehsan, Malaysia. E-mail: rahamah@pkrisc.cc.ukm.my
}

$\begin{array}{lc}\text { Received: February 17, } 2013 & \text { Accepted: April 2, } 2013 \quad \text { Online Published: June 1, } 2013 \\ \text { doi:10.5539/ass.v9n7p192 } & \text { URL: http://dx.doi.org/10.5539/ass.v9n7p192 }\end{array}$

\begin{abstract}
Malaysia has moved away from the sole breadwinner towards a dual breadwinner paradigm. Important criterion of success for such new paradigm is the integration of women and particularly of mothers, into the labor force. According to statistics compiled by the Statistics Department of Malaysia (1970, 1980, 1991 \& 2003) and Malaysia 2006, about 30.8 percent of women make-up the labor force in 1970. The percentage started to increase to 35.1 percent in 1980 , decreased slightly to 33.5 percent in 1991 and increased to 36.7 percent in 2005 . As for the male labor force, the pattern was the same, whereby the rate was 69.2 percent in 1970, decreased to 64.9 percent in 1980, increased again to 67.9 percent in 1991, but dropped to 63.3 percent in 2005 . The demographic shifts have resulted from the economic changes that requires most families to have two incomes for economic viability and from the women's desire to have both an active and fulfilling family life as well as a career. Men have begun to do slightly more household and childcare tasks as women are involved in employment. This article will highlight the strategies to sustain the dual earner in the workplace.
\end{abstract}

Keywords: sustainability, dual earner, flexibility, career planning, childcare services, training

\section{Introduction}

Malaysia has moved away from the sole breadwinner towards a dual breadwinner paradigm. The success of being a dual breadwinner is to being together female workers and particularly women with children into the labor force (William, 2000; Nadler et al., 2010). According to statistics compiled by the Statistics Department of Malaysia (1970, $1980 \& 1991 \& 2003)$ and Malaysia 2006, about 30.8 percent of women make-up the labor force in 1970. The percentage increased to 35.1 percent in 1980, decreased slightly to 33.5 percent in 1991 and increased to 36.7 percent in 2005 . As for the male labor force, the distribution was the same, whereby the rate was 69.2 percent in 1970, decreased to 64.9 percent in 1980, increased again to 67.9 percent in 1991, but dropped to 63.3 percent in 2005 . Though the participation of female workers show a good sign but their entry into the labor market has by no means guaranteed them access to top position and at the same time to be permanent in the labor market until the age of retirement. Research carried out by Friedman \& Greenhaus (2000) and Mesu et al (2013) showed that women who consider the family and work are important, is more likely to be in the managerial level positions. Although women have the same type of education as their male colleagues, they remain to be in low level type of jobs and have to fulfill the responsibility at home as a wife and mother (Whiting \& Wright, 2001; Risman \& Johnson-Sumerford, 1998; Cooper, Lewis, Smithson \& Dyer, 2001; Kelly 1997; Blair-Loy, 2003). This article will discuss the strategies to sustain the dual earner in the workplace. The discussion in this article is organized as follows. A write-up of the methodology and the literature review, followed by result and discussion. Strategies used to sustain the dual earner at the workplace is suggested in the final section.

\section{Methodology}

The data used in this article were part of a larger data taken from a research that examined employment segregation by gender. Purposive sampling was used. Sampling unit of 12 families were chosen from families that have three generations whether they are in the nucleus or extended family unit, bringing a total of 36 
respondents. The respondents are chosen using snowball technique. In this article, respondents classified as dual earner was selected as a case study. In-depth qualitative interview was used to obtain the required data and information. Participating respondents were considered eligible if (a) each spouse was involved in paid employment and (b) the couple had children who resided with them. Respondents need to answer the questionnaire and take part in the in-depth interview. The interview consist of semi-structured open-ended questions related to their role as a mother, wife and a worker and how the respondents cope with the responsibilities as a dual earner.

\section{Literature Review}

Haddock, Zimmerman, Ziemba \& Lyness (2006) carried out a study related to dual earner couples from three urban areas of Colorado. The data for the study were part of a larger research data. Forty-seven middle-class dual earner couples with children participated in the study. Both husband and wife in this samples categorised themselves as successful in balancing family and work. The study showed that workplace practices perceived as supportive in balancing work and family. The activities include flexitime, job autonomy, teleworking, good supervisors, and supportive colleagues and supervisees. Respondents also described that they maintain to be in one workplace that have family-friendly activities and the opportunity cost they are willing to take.

The most familiar work strategy in New Zealand is the male breadwinner syndrome and women working as -part-timers. This strategy creates problems for New Zealand's accountancy profession. Therefore, Whiting (2002) carried out a research to look at this issue. Respondents consisting of 27 male and female experienced chartered accountants was interviewed they gather the strategies they used to combine work and family responsibilities and how this relates to their career success. Whiting (2002) used the five-part typology, that is Traditional Men, Traditional Women, Work First Women, Family Balancers and Stepping Stone Men to describe the different strategies used. None of the typology selected was found in the findings. Therefore, a new family/work typology was developed that better described the more diverse patterns emerging with the interview data. The typology assumes that both the public and private spheres of society are an important factor to be considered.

Haas, Steinheimer \& Wallace (2003) carried out a research related to home-work balance in the Netherlands, Sweden and Austria. These three countries were chosen as perfect examples for the specific ways of integrating women into the labour market. The Netherlands, a conservative welfare state, are well-known for their part-time society. Sweden, with a socio-democratic, universal welfare regime, stands out for catering to women's interest. Sweden is known for its generous policy concerning gender equality and aim to a high labour force participation of women. The gender-specific division of labour in Austria with its conservative, employment-oriented regime, proves to be rather traditional. Secondary data was used, that is The Family and Fertility Survey 1996, Labour Force Survey 2000 and Household, Work and Flexibility Report 2000. The result can be summed up as follows: The relative significance of full-time employment for mothers has rarely been taken into consideration in Austrian policies. Austria shows a clear preference for private childcare. Austrians are in favour of mothers leaving their jobs. However, they also consider part-time work as the most sensible type of employment for women who need to look after their children. As in the Netherland, Dutch women are more likely to work in part-time jobs. In Sweden, the labour force participation of mothers plays an important role, whereby part-time work is limited to the first phase of childcare, when the child is still very young. When the child is grown up, mothers have a good chance to switch to a fulltime job.

\section{Result and Discussion}

Discussion related to empirical data was based on selected cases which give us the real picture of what is happening in the family of a dual earner. As more and more women enter the labor market, they will also have to face the strains of maintaining their dual roles, as family manager and working woman. Nevertheless, our respondents do not have difficulty in terms of their role as a family manager. They do get a helping hand from their husband in doing the housework and childcare. According to Schwartz and Zimmerman (1992), men have realized and begun to do slightly more household and childcare tasks than they did in the past. To what extend does the man really help the wife? According to our respondents, they (wife) do nearly all the housework. They frequently work a double shift, at work and at home and spend more time attending to housework and childcare duties compared to their husbands (Kelly, 1997; Summerskill, 2001). According to Aida who worked as an assessment officer:

My daughter aged seven is being taken care of by a friend. My husband will send her every morning and it will be my turn to fetch her every evening after work. This duty looks like a normal routine but at times it put pressure on you especially when my daughter or the carer is sick. I have to take leave. I was 
lucky to have an understanding husband (a general manager in a private company) that helped with the housework such as to put the clothes into the washing machine and hang it out. Usually this was done at night or in the morning before going out to work. I work six days a week while my husband work five days a week. He will help to clean the house over the weekend especially on Saturday.

Another respondent who worked as a nursery teacher get help from her husband who worked as an engineer in doing jobs such as washing the clothes and cleaning the house. She does not have a helper although she can afford it and the housework is always carried out over the weekend. Respondent started her daily routine as early as between 4.00 a.m - 5.00 a.m. and ends between 10.00 p.m - 12.00 midnight. She has to get up early to do the daily domestic task before going out to work. In the morning, domestic work carried out are cleaning the house, preparing breakfast and washing the clothes. After work, she will do the cooking and bathing the children. Holding a high position in the organization as an engineer or accountant does not hinder men to do the housework.

Certainly, in dual-career couples, careful planning and organization can help to alleviate some of the domestic pressures. In addition to providing inadequate day care nursery facilities, many organizations still make little provision for career women who take time off to raise children, and then return to the workforce to continue their careers. An internal auditor in a banking organization described their policy towards returning to the workforce:

More women are now proving that they can do the job and are committed to a career. There is still this thing from male managers that it's no good putting money into training women because they are going to leave in a few years anyway to have children. I think women have got to show either they are not going to leave at all, or if they do, they are going to return very quickly. They must have the opportunity to come back.

Work culture plays an important role in supporting work-family balance. Thomas \& Ganster (1995) found that supportive supervisors had direct positive effect on employee perception of control over both work and family. The respondents interviewed assert that they generally received encouragement from superiors, and relationships were usually good. According to Aida who worked as an assessment officer:

I have a male superior and often received encouragement from my boss and work relationship was usually good. He does not have the assumption that women are poorly qualified. In order to gain additional support from my boss, I have to succeed in being perceived as being more competent than my male counterparts. Relationship with my male and female colleagues is also good. In terms of salary, there is no discrimination. However, there appeared to be a sex differential with regard to promotion. The chances for promotion depend on the individual's capabilities and are more open for the male workers. Women workers compared to their male colleagues require additional qualities to be able to succeed in her career. We should said that working woman should have additional qualities to be able to succeed in her career. Women should be efficient in carrying out her work, have potentials to be an administrator, and committed to the work place.

Linda, aged 28 years old is the eldest child in the family, had a son aged 4 months. The highest level of education received by Linda is a first degree, majoring in accounting from a local university. She had been married for two years to an assessment officer. She had been working as an auditor for nine years, that is since 1995, before marriage, with a monthly salary of RM2700.00. She chose to work as an internal auditor, her first job because of her qualification. As Linda had said:

Woman is more appropriate to work with a male boss and which I had one. Male superior is more flexible. He does tend to treat me differently from my male colleagues. My boss tend to rely on me more as I think he see me as being more efficient. From my opinion, although my boss acted positively, the pressure is still there to be better than a male. With regard to relationships with colleagues, I feel women should work hand in hand with male and female colleagues. However, I saw that my male colleagues of similar or equal status are competitive, create stress, and at times seem to be threatened by them. Male colleagues see me as still have some opportunity for promotion. Some men workers feel jeopardized when they know that few women workers are in the decision-making level. Most men are not concerned about an efficient women being in the decision-making level but they are more worried about a less competent woman achieving success over them. My relationship with male and female subordinates was also good. Most of the men who worked for me have carried out their work efficiently. They are approachable and can discuss the problems they are having with work. For a woman like me to achieve success in my career, I need to be open-minded and be creative. 
It is the second generation in the family. Her highest level of formal education is the Diploma she received from a private college. She is married for four years and had two children, the eldest a boy age three years old and the second one was a girl aged seven months. Ita worked as a secretary in a private firm. Although she had been working for six years, her boss always insist her to further her studies. This lead to problems because she is not ready due to her responsibility towards the family and have to assist her husband in terms of finance. This is her first job and had been working before getting married. Her husband gave full support for her to continue working. Her work place is quite far from her place of stay and it takes about 45 minutes driving. She had no problems about her two children because they are being taken care of by her own mother who stayed nearby. Usually she reached home at about 7.00 p.m. Her husband is working as a remiser and do not have a fixed working hour. Ita was asked about her work experience and some interesting outcome were observed:

I am working under a male boss and I preferred male to female boss. Male boss were more helpful and tolerant. They also possess qualities such as efficiency, hard working, frankness and realism. I feel female bosses are very firm. With regards to relationship with colleagues and subordinates, there are no differences. My female and male colleagues and subordinates give full support. We work together and there will always be a two-way communication.

\section{Strategies to Sustain the Dual Earner in the Workplace}

The number of female workers entering the labor market is increasing from year to year. With this increase, it is incumbent on organization to develop corporate personnel policies that will minimize the current pressures on female and male workers. The most common policy is workplace flexibility (Christensen \& Staines, 1990; Ezra \& Deckman, 1996; Galambos \& Walters, 1992; Galinsky, Bond \& Freidman, 1996; Gerson \& Jacobs, 2001; Holt \& Thaulow, 1996; Kropf, 1997; Marshall \& Barnett, 1994; Pleck, 1993; Thomas \& Ganster, 1995; Haddock, Zimmerman, Ziemba \& Lyness, 2006). Flexibility include flexitime or the ability to have flexible starting and ending work times (Christensen \& Staines; 1990). The other strategies involved to sustain the dual earners are career planning, childcare services and training.

\subsection{Workplace Flexibility}

There is a wide range of flexible working arrangements that organizations can provide for the male and female employees to help them to accommodate changing family patterns. They are (a) flexi-time, (b) flexi-year and (c) part-time work.

1) Flexi-time is obviously one good example. In order that a dual-career wife or husband can meet the psychological responsibilities associated with their children's education, many parents feel that they must take their children to childcare center and /or pick them up. This is very difficult to accomplish under the usual 9 to 5 (or later) working arrangements, and would be made much easier under flexible working hours conditions. Flexi-time is not only useful during the working week but also during school holidays.

2) Another innovative form of flexible working arrangement is flexible working years or flexi-year. Within this system, employees working hours can be set for the whole year and then individuals can have their own working time in order to fulfill the yearly quota. This has advantages for both the employee and the organization. The employee is provided with the flexibility to work longer hours at certain periods and reduce working during periods such as school holidays, while retaining a secure and regular system of payment. Payment is by means of a regular monthly salary, regardless of the number of hours worked during that period. The benefits to employers will obviously depend upon the nature of the organization. This benefit enabled employers to handle seasonal or cyclical fluctuations because of a more flexible workforce. The firm is able to take full advantage of a vast pool of full-time, part-time, job-sharing and seasonal staff. By fitting working time to employee's needs, there is greater productivity and lower absenteeism and turnover.

3) Another more flexible working arrangement would be part-time work in various forms such as limiting the number of days a week, limiting the number of hours in a day or shortening the working week by allowing individuals to work three or four-day, 40-hour weeks.

\subsection{Career Planning}

This include (a) V-time (voluntary reduced time) and (b) career-break schemes.

1) Voluntary reduced time is a system that allows full-time employees to reduce working hours for a specified period with a reduction in salary. This system is different from the normal concept of part-time work. V-time is temporary in nature with a return to full-time work guaranteed. All employee benefits will be maintained, although they may be altered to a pro-rata basis. The schedule should remain in force for an agreed period, perhaps 6 or 12 months, to enable employees and employers to try it out, with an assurance that the commitment 
can be renegotiated or terminated. The 'time off' can be taken by working shorter days or weeks or a block of time may be taken, perhaps during school holidays. V-time can also be used for employees to gain new skills or facing with health problems.

2) Career break schemes is another form of career planning. Many women prefer to spend more time with their infants than maternity leave allows. Working women in Malaysia have the right for a 60 days maternity leave, a maximum of five times throughout her employment service. She is also eligible for leave to look after the newborn child for 90 days without pay with effective from the 61 day after her maternity leave. Maternity leave for women workers in Malaysia is still short compared to the developed countries. Various facilities should be implemented to enable mother to develop their career such as re-entry and retainer schemes. These schemes allow women workers to have a break for a few years within their career and to return to work with no loss of seniority. The employee can undertake at least two weeks' paid relief work for the company during each year of her absence, and is provided with regular information packs, as well as a refresher course on her return. The scheme may permit one five-year break or two shorter breaks, each dating from the end of statutory maternity leave. Career breaks are open, in principle, to men as well as women, although in practice they tend to be taken only by women.

\subsection{Childcare Services}

Childcare services are provided to support parents in managing the tension between paid work and care giving responsibilities. Increasingly throughout Malaysia, organizations are beginning to provide in-house day-care centers for their employees' children although the number is very small. Employers are facing with problems in setting up childcare facilities. There are too many government requirements and regulations to be fulfilled, that is:

- Need to have approval from the Ministry of Education, Fire Brigade Department and Ministry of Health

- Need experts to handle the children. Staff should be permanent.

- High cost to build child-care centers

- Need to have a suitable environment - electronic factory is not suitable

Childcare facilities for the children of female workers can ease the transition to parenthood and can eliminate the need for extended career breaks. Difficulty in making childcare arrangements is the primary obstacle to women returning to work after maternity leave. There are several types of leave and option that may be taken by parents when a child is born, other than maternity leave, that is (a) paternity leave and parental leave, (b) workplace nurseries, (c) caring for sick children, and (d) after-school childcare.

1) Paternity leave is granted only to fathers for a limited period around the time of childbirth. In Malaysia, fathers were entitled to seven days of paternity leave when the child was born. These days are supposed to be used either to take care of the mother and the newborn baby or to take care of older children in the family. Parental leave is often seen as a measure to gender equality by encouraging more continuous labor force attachment among women and promoting fathers' participation in childcare. Parental leave can be taken both by mothers and fathers. In Sweden the parental leave is 480 days or 16 months and is very flexible. It is possible to choose between full, three quarter, half, one quarter or one eight (that is one hour) of a day.

2) Workplace nurseries have traditionally been provided in organizations such as hospitals that employ large numbers of highly trained women and recognize the importance of accommodating their childcare needs. The cost of setting up and running a workplace nursery is often considered to be prohibitive, but this should be seen as a benefit in kind similar to, and equally essential as, a canteen or sports and social clubs. A workplace nursery has economic as well as qualitative benefits. Savings were calculated in terms of recruitment and retaining, due to the rise in the number of female workers returning after maternity leave, as well as in the benefits of reduced stress, decline in absenteeism and improved time-keeping. A creche or on-site nursery located very near to the place of work has several advantages over other forms of childcare. Parents can see their children during the day and are readily available in an emergency, it is invaluable for mothers who return to work while still breast-feeding, and the hours coincide with those of the working day.

3) The dilemma which occur when a child or the child's carer is sick cause parents considerable stress. Mothers can be ill themselves because taking time off to look after a sick child, was not considered legitimate by their employers. Working mothers were compelled to use up holiday time. Although paid leave to care for a sick child should be available, it must be recognized that many employers are reluctant or unable to drop everything to 
cope with this situation. Therefore, alternative policies should be implemented to help parents cope with a sick child without taking time off work.

4) Childcare problems do not disappear once a child begins school. In some ways, the situation becomes more difficult as the length of the school day is shorter than the working day. After school child-care is also important. Organization can assist by arranging to transport children from schools to their parents' workplace and by providing after-school childcare programmes. School holidays can also present a problem for children too old to attend a nursery but too young to be left alone. Organizations or groups of organizations could assist by offering holiday childcare for employees children. Perhaps more fundamentally, it is important that parents are given the opportunity to take their vacation to coincide with school holidays. Flexible working arrangements can be used to enable parents to work longer in term of time and save up time to allow them a longer break during school holidays.

\subsection{Training}

1) Career planning, counseling and training. Some working women have special needs such as counseling, training and planning for their career. It is important to plan and give counseling to these women about their career goals. The appropriate activities include retraining, deskilling or updating their career performance.

2) Provide mentoring system. To encourage and help support women to stay in the labor market for sometimes, a mentor-mentee system should be introduced in the organization. This system would help the female workers to meet their mentors, to better understand the organization's informal procedures and customs, and to provide her with any other procedures related to a working life (for example, myths about the company, or its history).

3) Helping male workers to come to terms with female workers. Training programmes should be established in the organization for the workers to share their perceptions, myths and feelings about one another, in particular the role of women in the labor market and particularly in the organization. The main objective is to try and change male workers' perception about their counterparts.

4) Informal support networks for female workers. This may be particularly helpful while female workers are still very much being minority in the organization, but less necessary as they begin to establish themselves in larger numbers and throughout the organization.

\section{Methods to Implement Strategies Effectively}

Employers play an important role in helping women workers to cope with the domestic and work environment. Organizations should encourage both women and men to be involved in the labor market, and at the same time provide them with career opportunities which is 'woman-friendly'. The strategies being suggested need to be implemented effectively in order to be successful. There should be a clear and serious commitment on the part of the policy makers, employers and also employees' concerned, to implement the strategies effectively. There should be a follow-up to the commitment to set up appropriate action for planning and evaluating the strategies to sustain the dual earner in employment. An effective method of communication between the parties concerned is very important. Ways these strategies should be carried out are:

1) Campaign to change mind set among policy makers and employers to make them aware on employment based on merits

2) Due recognition among workers about the important of equal participation of labor force

3) Facilitating dialogue among decision makers, employers and employees concerning the selection of appropriate strategies into practice.

4) Develop awareness among top managerial levels engaged in the key division regarding the strategies designed which requires collective action and a participatory and transparent type of involvement, in which the fact that those taking the decisions display personal commitment for the strategies to be implemented successfully.

\section{Conclusions}

Changes in the participation of women in the labor market can be seen as a most serious threat to the sustainability of the Malaysian dual earner. Women and men's relative employment rates influence the dual earner model. The participation rate of women and men in the labour market today are almost the same as compared to 1970. The employment rates are more similar for women and men in 2005 than 1970. This article conforms the dual earner literature review and showed that employers and policy makers play an important role to the employees' family success. Parental leave have a positive effect on the continuous involvement of women and men in the labour market. Women are more likely to enter the labor market if they were given full paid leave with a return to full-time work guaranteed. If women develop a job attachment before becoming pregnant, it is 
more likely that they return to work after leave. However, maternity leave should not be very long. It may result in a significant work life interruptions, which might affect women's career possibilities and promotion. Long periods of unpaid leave taken almost entirely by women, have the effect of reinforcing gendered divisions of labor both in employment and childcare. It is suggested that the parental leave should not be too long.

From the discussion, it can conclude that the dual earner model seems to be rather sustainable, but this does not mean that there are no challenges in the future. Individuals can react positively to the economic situation and exploit the possibilities. This is true for childcare. Women's continuous involvement in the labour market generated a demand for childcare facilities. However, when the quantitative supply of childcare has been the focus, the qualitative aspect arises. Individuals on the other hand do not always, for some reasons, react in line with what had been suggested to them. Strategies that had been suggested are more effective if they are of "bottom-up" type, from the working women's point of view, than if they are "top-down", from the employer's point of view.

\section{References}

Blair-Loy, M. (2003). Competing Devotions: Career and Family among women executives. Harvard University Press, Massachusetts.

Christensen, K. E., \& Staines, G. L. (1990). Flexitime: A viable solution to work/family conflict? Journal of Family Issues, 11, 455-476. http://dx.doi.org/10.1177/019251390011004007

Cooper, C., Lewis, S., Smithson, J., \& Dyer, J. (2001). Flexible futures: Flexible working and work-life integration. London: Institute of Chartered Acountants.

Ezra, M., \& Deckman, M. (1996). Balancing work and family responsibilities: Flexitime and child care in the Federal Government. Public Administration Review, 56, 174-179. http://dx.doi.org/10.2307/977205

Friedman, S. D., \& Greenhaus, J. H. (2000). Work and family-Allies or enemies? New York: Oxford University Press. http://dx.doi.org/10.1093/acprof:oso/9780195112757.001.0001

Galambos, N. L., \& Walters, B. J. (1992). Work hours, schedule inflexibility and stress in dual-earner spouses. Canadian Journal of Behavioural Sciences, 24, 290-302. http://dx.doi.org/10.1037/h0078743

Galinsky, E., Bond, J. T., \& Friedman, D. E. (1996). The role of employers in addressing the needs of employed parents. Journal of Social Issues, 52, 111-136. http://dx.doi.org/10.1111/j.1540-4560.1996.tb01582.x

Gerson, K., \& Jacobs, J. A. (2001). Changing the structure and culture of work: work and family conflict, work flexibility and gender equity in the modern workplace. In R. Hertz, \& N. L. Marshall (Eds.), Working families: The transformation of the American home. Berkeley, CA: University of California Press.

Haas, B. (2003). Work-home balance in Austria, the Netherlands and Sweden: Is it possible to identify models? Sociological Series 59, Department of Sociology, Institute for Advanced Studies, Stumpergasse, Vienna.

Haddock, S. A., Zimmerman, T. S., Ziemba, S., \& Lyness, K. P. (2006). Practices of Dual Earner Couples Successfully Balancing Work and Family. Journal of Family and Economic Issues, 27, 207-234. http://dx.doi.org/10.1007/s10834-006-9014-y

Holt, H., \& Thaulow, I. (1996). Formal and informal flexibility in the workplace. In S. Lewis, \& J. Lewis (Eds.), The work-family challenge: Rethinking employment. Thousand Oaks, CA: Sage.

Kelly, R. M. (1997). Sex role spillover: Personal, familial and organisational roles. In D. Dunn (Ed.), Workplace/women's place. Roxbury, Los Angeles.

Kropf, M. B. (1997). A research perspective on work-family issues. In S. Parasuraman, \& J. H. Greenhaus (Eds.), Integrating work and family: Challenges and choices for a changing world. Westport, CT: Quarum.

Marshall, N. L., \& Barnett, R. C. (1994). Family-friendly workplaces, work-family interface, and work health. In G. P. Keeta, \& J. J. Hurrell (Eds.), Job stress in a changing workforce: Investigating gender, diversity and family issues. Washington, DC: APA. http://dx.doi.org/10.1037/10165-016

Mesu, J., Riemsdijk, M. V., \& Sanders, K. (2013). Labour fkexibility in SMEs: the impact of leadership. Employee Relations, 35(2), 120-138. http://dx.doi.org/10.1108/01425451311287835

Nadler, J. T., Cundiff, N. L., Lowery, M. R., \& Jackson, S. (2010). Perceptions of organizational attractiveness: the differential relationships of various work schedule flexibility programs. Management Research Review, 33(9), 865-876. http://dx.doi.org/10.1108/01409171011070297

Pleck, J. H. (1993). Are "family-supportive" employer policies relevant to men? In J. C. Hood (Ed.), Men, work 
and family: Research on men and masculinities. Newbury Park, CA: Sage.

Risman, B. J., \& Johnson-Sumerford, D. (1998). Doing it fairly: A study of postgender marriages. Journal of Marriage and the Family, 60(1), 23-40. http://dx.doi.org/10.2307/353439

Summerskill, B. (2001). Myth of the mighty mum. The Press: Christchurch.

Thomas, L. T., \& Ganster, D. C. (1995). Impact of family-supportive work variables on work-family conflict and strain: A control perspective. Journal of Applied Psychology, 80, 6-15. http://dx.doi.org/10.1037/0021-9010.80.1.6

Whiting, R. H. (2003). Implications of work/family strategies on Chartered Accountants' Career status. Department of Accountancy and Business Law, University of Otago, Dunedin, New Zealand.

Whiting, R. H., \& Wright, C. (2001). Explaining gender inequity in the New Zealand Accounting Profession. British Accounting Review, 33, 191-222. http://dx.doi.org/10.1006/bare.2001.0161

Williams, J. (2000). Unbending gender: Why family and work conflict and what to do about it. New York: Oxford University Press.

\section{Copyrights}

Copyright for this article is retained by the author(s), with first publication rights granted to the journal.

This is an open-access article distributed under the terms and conditions of the Creative Commons Attribution license (http://creativecommons.org/licenses/by/3.0/). 